\section{The Use of Audit Opinion in Estimating the Financial Reporting Transparency Level}

Lecturer loan Bogdan ROBU, Ph.D., "Alexandru loan Cuza" University of laşi, Faculty of Economics and Business Administration, Romania, e-mail: bogdan.robu@feaa.uaic.ro

Univ. Prof. Costel ISTRATE, Ph.D., "Alexandru loan Cuza" University of laşi, Faculty of Economics and Business Administration, Romania, e-mail: istrate@uaic.ro

lonut Viorel HERGHILIGIU, Ph.D., "Gheorghe Asachi" Technical University of laşi, Faculty of Chemical Engineering and Environmental Protection Romania, e-mail: herghiligiuionut@gmail.com

\section{ABSTRACT}

Information presented to stakeholders through a system of standardized indicators and transparency in financial reporting are the basis in the decision-making process for a sustainable development of the companies. The purpose of this study is to analyze and assess the transparency in financial reporting, assessed based on the audit opinion, and the influence of determinant factors on transparency, using logistic regression. The determinant factors are expressed by principal dimensions of financial statements identified through the Principal Component Analysis applied on the indicators of position and performance. The observed sample consists of 62 companies listed on Bucharest Stock Exchange during the period 2011-2016. The main results reveal the existence of three principal components of the financial statements, Cash flow component, Return component and Current assets structure component; among these dimensions, only the return component has significant influence on transparency in financial reporting assess through the audit opinion.

Keywords: sustainable development, transparency, financial reporting, audit opinion, principal component analysis, logistic regression

JEL Classification: C58, M41, M42

To cite this article:

Robu, I-B., Istrate, C., Herghiligiu, I. V. (2019), The Use of Audit Opinion in Estimating the Financial Reporting Transparency Level, Audit Financiar, vol. XVII, no. 1(153)/2019, pp. 79-92, DOI: 10.20869/AUDITF/2019/153/001

To link this article:

http://dx.doi.org/10.20869/AUDITF/2019/153/001

Received: 16.01.2019

Revised: 17.01.2019

Accepted: 23.01.2019 


\section{Introduction}

During the last decade, companies were encouraged by United Nations (UN) members' governments to adopt the principles of sustainable development in their corporate governance act (Labuschagne, Brent, and van Erck, 2005). The use of these principles leads companies to achieve some objectives regarding the environment protection, social equity and economic prosperity (Bansal, 2005). The result of achieving these objectives by the companies is reflected through transparency in the reporting the sustainable development (Heemskerk et al., 2002). Under the stakeholders' pressure, the analysis of this type of information allows the evaluation of the sustainable performance (Heemskerk et al., 2002).

Transparency in the environmental reporting of company aims to present the activities related to prevention and control of the environment pollution (Heemskerk et al., 2002). As for the social equity, the transparency in companies' reporting must ensure the disclosure of the company's activity in the field of social responsibility (Heemskerk et al., 2002). For the third dimension, the economic prosperity, the transparency considers the disclosure, in a standardized form, the faithful representation of the financial position and performance, according to a reporting framework (Patel et al., 2002).

By ensuring compliance with an applicable reporting framework, transparency in financial reporting leads to a reduction in information asymmetry (Hayes et al., 2005). The compliance with the reporting framework is confirmed by a third part, an independent and objective professional, namely a (financial) auditor. Within his engagement, the scope of the financial auditor is to provide an opinion on the quality of the information from the financial statements of the audited company, regarding the financial position and performance, according to the applicable accounting standards (IAASB, 2016).

The purpose of this study is to analyze and evaluate the influence of the financial statements' dimensions on the transparency in financial reporting. In this study, we propose assessing transparency of the financial statements using the auditors' opinions, assuming that financial statements are transparent if an unqualified opinion or an unqualified opinion but with insignificant observations are provide by the auditors.
A first objective of this study is to determine the information content, by estimating the dimensions of the financial statements. A second objective involves the analysis and assessment of the financial statements dimensions' effect on ensuring transparency in financial reporting.

The study was carried on a sample of 62 Romanian companies, listed on the Bucharest Stock Exchange (BSE), between 2011 and 2016. The study results revealed the existence of three dimensions of financial statements, identified by principal component analysis and the estimation of each dimension's influence on the transparency in financial reporting, using logistic regression analysis, based on audit opinion.

Further, the study is structured as follows: section 2 Literature review and hypotheses development, section 3 - Research methodology, section 4 - Results and discussions, section 5 - Conclusions.

\section{Lîterature review and hypothesis development}

Sustainability reporting at the corporate level requires a transparent disclosure of the companies' activity, having as reference the reporting requirements included in the Global Reporting Initiative (GRI) (Ortas, Alvarez, Garayar, 2015). Sustainability and integrated reporting represent important global trends that cannot be achieved without the support of accountants, in their position as producers of financial information, but also as auditors (James, 2014). An analysis of this type of information allows the assessment of sustainable performance (Labuschagne, Brent, and van Erck, 2005; Visser, 2002), and the degree to which social and environmental elements reported by the listed companies are useful to all stakeholders in decision making.

\subsection{Sustainable development reporting}

Implementation of sustainable development principles to all business levels has allowed companies to obtain competitive advantages compared to companies that do not apply such principles (Lopez, Garcia, Rodriguez, 2007). Therefore, optimal decisions in a business can only be made by considering all economic, social and environmental consequences (Labuschagne, Brent, van Erck, 2005; Hockerts, 1999). However, assigning 
resources to investments taking into account sustainability objectives implies a cost or reallocation of resources that may negatively affect the firm's performance (Lopez, Garcia, and Rodriguez, 2007; Orlitzky, Schmidt, and Reynes, 2003).

Evaluation of entities contribution to sustainable development can be achieved based on information reported by the company on Corporate Social Responsibility (CSR) (Lungu at al., 2011; Farcaş, 2015). CSR involves organizing business by applying the principles of corporate social responsibility, ensuring a balance between the firm's activities, environment and society (Fauzi, Svensson, Rahman, 2015).

Through Directive 2014/95/EU on disclosure of nonfinancial information and diversity Undertakings by Certain large companies and groups companies are recommended to present, in the reports of those in charged with governance, information about policies, risks and achievements in terms of the environment, employees and other social elements, human rights, fighting corruption, diversity management structure. The stated purpose of this kind of complementary financial reporting is to provide stakeholders a clearer picture of overall performance of companies.

Sustainability information is published often in a voluntary manner and without enough control from independent institutions (Lackmann et al., 2012). But the credibility of sustainability reporting and performance ensure the usefulness and relevance of information to investors and help to establish the market value of a firm (Lackmann et al., 2012). To ensure credibility, by Directive 2014/95/EU it is recommended the need to audit these reports in order to express an opinion by the auditor on such non-financial information published by eligible companies.

In the case of sustainability reporting, indicators that are used should provide the necessary information on the manner in which the company contributes to sustainable development (Krajnc \& Glavic, 2005a; Azapagic \& Perdan, 2000; Azapagic, 2004). However, only some of the sustainability indicators used to assess corporate sustainable development have an integrated approach taking into account environmental, economic and social aspects (Singh, Murty, Gupta, \& Dikshit, 2009).

The relationship between indicators of performance and those of sustainability has been studied by many authors
(Bansal, 2005; McWilliams \& Siegel, 2000; Preston \& O'Bannon, 1997; Stanwick \& Stanwick, 1998; McGuire, Sundgren \& Scheneweiss, 1988). For measuring the progress and the performance of companies towards sustainable development systems specific methodologies of core and supplemental indicators are necessary (Krajnc \& Glavic, 2005b). The sustainability indicators that are used to assess corporate sustainable development are based on composite index (Singh, Murty, Gupta \& Dikshit, 2009).

\subsection{Financial disclosure and the usefulness of financial information}

Financial reporting must ensure to all the users a faithful representation of the financial position and performance of the companies during a financial year. The financial position and performance, as well as the information regarding the cash flows of companies are reflected in the standardized parts of the companies' financial statements (IAS 1, IASB, 2015). These financial statements include information than can reduce the uncertainty regarding the evolution of the companies and are useful to stakeholders in decision making process (Arrow, 1984, p. 138, quoted in Shapiro \& Varian, 1983).

Financial statements can meet the information exigencies of the shareholders and ease the communication of the financial information, with significant impact on planning and coordinating the activities within the company (Palttala \& Vos, 2012). By knowing certain elements regarding the profitableness, profitability, the cost of the used capital, the indebtedness or solvability degree of a listed company, investors can decide on buying or selling the shares of that company for a certain price. The result of the meeting of the offer and the demand for certain shares, the price can be also influenced by the yield they offer (Modigiani \& Miller, 1958).

The standardization efforts of financial reporting are also determined by the need of ensuring qualitative CSR. For better information of stakeholders, the implementation of the IFRS (International Financial Reporting Standards) intend to lead to an improvement of financial information quality (Barth et al., 2008) and also of the non-financial one, with direct impact on the CSR. But informational the need is different for each category of stakeholders, and this diversity could represent a barrier for the 
materialization of the CSR development efforts (Tschopp\&Nastanski, 2014).

Improving the information quality through IFRS led to an implicit increase on its relevance for investors (Barth, 2008). But according to the types and dimensions to which they disclosed, financial information has a different relevance for investors, with a variation of the influence on the share price or market capitalization (Ohlson, 1995; Sloan, 1996; Brown et al., 1999; Barth et al., 2008).

In Romania, the transition to the IFRS in the individual financial statements of listed companies was made in a very short period of time (the norm was published in June 2012 for a mandatory application starting with the 2012 financial year). In fact, the application of IFRS in Romania was stimulated by the recommendations of the international financial organizations (the World Bank and the International Monetary Fund), as well as the affiliation of some Romanian companies to multinational groups whose reporting referential is represented by the IFRS (Bunget et al., 2009). Initially, the transition to IFRS has had a significant impact especially in the individual accounts of Romanian listed companies (Ionaşcu et al., 2014). Subsequent studies revealed that the transition to IFRS led the Romanian listed companies to a slight increase in total equities, to a significant decrease in net income and operating income, which affected the values of profitability indicators (Săcărin, 2014; Istrate, 2014).

Although, by introducing IFRS, it was expected that in Romania to get a major increase of financial information quality, in the case of BSE listed companies there is a persistence of IFRS accounting policies versus RAS - Romanian Accounting Standards (Istrate, 2015). Based on these records it can be further considered that accounting result has a high relevance for investors, unlike other elements of financial statements (Filip \& Raffournier, 2010).

\subsection{Transparency in sustainability reporting and in financial disclosure}

CSR reports are useful to stakeholders when they provide information regarding the whole activity of the company, in a transparent manner, not only with declarative objectives, or as a marketing and public relations tool (Boerner, 2011).

For measuring the transparency at the corporate level, it can be analyzed information from the annual reports, grouped into three sub-categories: ownership structure and investors' relations, financial transparency and information disclosure, board and management structure and process (Patel et al., 2002). From approximate 40 attributes retained for financial transparency and information disclosure, the most important are related to: the presentation of the applicable accounting rules, the analysis by business segments, the name of the audit firm, the audit report, the audit and non-audit fees, the efficiency indicators - ROA (return on assets), ROE (return on equities), NM (net margin) (Adiloglu şi Vuran, 2012). Although transparency and disclosure do not necessarily lead to an increase in operational performance of companies, they improve the investors' perception on the company's governance, with direct implications on their market value (Stiglbauer, 2010).

Transparency in multidimensional reporting (financial, environmental, social etc.) also causes new problems to the auditors, who must express an opinion on the way in which such information are relevant to investors (Abeysekera, 2013). As for the financial information, transparency represents an important part of corporate governance, leading to the reduction of the informational asymmetry and to the increase of trust on financial markets, which contributes to the reduction of the cost of capital (Patel et al., 2002; Stiglbauer, 2010).

Financial reporting obligations of listed companies are established by complex and precise set of rules regarding transparency of information to provide for stakeholders. Both American standards (US GAAP Generally Accepted Accounting Standards United Stated) and international (IFRS) are becoming more comprehensive as dimensions and include more stringent reporting rules complementary to the financial ones. In addition, the annual financial statements are often, part of an annual report that includes non-financial issues related items disclosed voluntarily.

The conformity of financial information with the applicable accounting reporting framework is ensured by the independent, objective and competent opinion expressed by a financial auditor (Hayes et al., 2005). The audit opinion is the most important section within the audit report, issued in accordance with ISA International Standards on Auditing. The report issued by an auditor contributes to the improvement of transparency and the growth of the relevance of the information from financial statements, by including some elements related to the reporting quality, the going 
concern assumption, the presence of the fraud risk and even to sustainable development (Jerry L. Turner, Theodore J. Mock, Paul J. Coram, and Glen L. Gray, 2010).

\subsection{Hypothesis development}

The purpose of financial reporting is to reduce the information asymmetry as the basis of faithful representation, to determine the business value and to facilitate the managers monitoring (Pinnuk, 2012). Applying a certain reporting framework may influence the reporting dimensions, with a direct impact on transparency and particularly on the profitability of companies shares (stock returns) (Morris et al., 2011). Among the principles that are used in preparation and presentation of financial statements and the principles of sustainable development there is strong correlation (Dobre et al., 2015). In this regard, assuring transparency in financial reporting should lead to transparency of sustainable development reporting at the corporate level.

Given the results presented in the literature, the main research hypothesis proposed for testing consider the following:

Research hypothesis: the dimensions of the financial statements have a significant influence on the transparency in financial reporting, with direct impact on sustainable development.

In a first step, the research objective is to identify the principal dimensions of the financial statements of companies that apply principles of sustainable development. Once identified dimensions of financial statements, in the second step there will be estimated their influence on transparency in financial reporting, to assess the impact on sustainable development.

\section{Research methodology}

To reach the research objectives, in this study we propose a statistical demarche to estimate the influence of the principal dimensions of the financial statements on transparency in financial reporting, with direct impact on the sustainable development. In this study, transparency in the financial reporting is evaluated based on the auditing opinion, expressed by the auditor in his issued report.

\subsection{Research population an sample}

Formulated research hypothesis will be tested on the population represented by Romanian companies listed on the Bucharest Stock Exchange (BSE). BSE listed companies should report, in all cases, annual financial statements for a period that covers the annual year. Financial statements of the BSE listed companies were to be made until 2012 according to the Romanian accounting standards (harmonized with the European directives), but, starting from 2012, companies were mandated to use the IFRS for their individual accounting. These financial statements of the Romanian BSE listed companies make the subject of mandatory auditing carried out by an independent auditor, member of the Financial Auditors Chamber in Romania, then making the subject of approval by the Shareholders' General Assembly (SGA). Romanian law stipulates, in principle, a limit term of 4 months from the end of the financial year, in order to publish the audited and approved annual financial statements.

At the end of the 2017 financial year (was considered this year because it represents the year of adoption of Law 162/2017), 84 companies were listed on the BSE section (24 in the Premium class and 60 in the Standard class). In our study we retained only 62 companies, after elimination of those whose activities are predominantly of financial (financial and monetary intermediates, mutual and investment funds) and those for which we have not found enough information. The period studied covers 2011 (the latest year of reporting under RAS), plus the period between 2012 and 2016, when the Romanian listed companies apply IFRS for individual financial statements. The analysis is performed on the individual financial statements because there are few BSE listed companies that consolidate their accounts. To ensure comparability of data collected, for a number of 372 observations (firms / year) in this study we used a balanced sample.

\subsection{Variables and data source}

Based on the structure of financial statements recognized under accounting standards (including IAS 1 - Presentation of Financial Statements) in Table no. 1 we propose the analyzed variables. 
Table no. 1. Independent variables used for the identification of the principal financial reporting components

\begin{tabular}{|c|l|}
\hline Symbol & \\
\hline Eq/TA & Total equities/Total assets \\
\hline TO/TA & Turnover/ Total assets \\
\hline OI/TA & Operating Income/ Total assets \\
\hline OI/TO & Operating Income/ Turnover \\
\hline Ol/Pay & Operating Income/Payroll expenses \\
\hline NI/Eq & Net Income/ Total equities \\
\hline NI/TA & Net Income/Total assets \\
\hline NI/TO & Net Income/ Turnover \\
\hline CFO/OI & Operating cash flows/ Operating Income \\
\hline CFT/TO & Total cash flows/ Turnover \\
\hline CFT/GP & Total cash flows / Gross profit \\
\hline CFT/TA & Total cash flows / Total assets \\
\hline FA/TA & Fixed assets/ Total assets \\
\hline CA/TA & Current assets / Total assets \\
\hline Cash/TA & Cash and cash equivalents/ Total assets \\
\hline INV/CA & Inventories/Current assets \\
\hline REC/CA & Receivables/ Current assets \\
\hline Cash/CA & Cash and equivalents/ Current assets \\
\hline LTD/TA & Long-term debts/ Total assets \\
\hline FL & Total liabilities /Total equities \\
\hline
\end{tabular}

Source: Own projection

Variables from the Table no. 1 are indicators, with informational content, that describe financial position and performance of the company and the cash flows statement. These variables are used to identify the principal dimensions of financial reporting.

To assess transparency in financial reporting, with direct impact on sustainable development, in this study we used the audit opinion. An unqualified opinion or an unqualified opinion but with no significant observations reveal transparency in financial reporting and compliance with applicable financial reporting framework (ISA 700 - IAASB). In other cases, when the audit reports contain modified opinions (a qualified opinion, an adverse opinion or the disclaimer of opinion) it is considered that transparency in financial reporting is affected.

For indicators calculated data were collected from the financial statements reported by companies on BSE website (bvb.ro) and on their websites.

\subsection{Methods for data analysis}

To identify the dimensions of financial reporting in the case of Romanian BSE listed companies, the study uses the principal component analysis (PCA). The principal component analysis is a multivariate descriptive method (Lebart et al., 2006) whose scope is to reduce the analyzed data, based on their common nature and to identify latent variables (Jaba \& Robu, 2011). Through this method, starting from the initial $X_{i}(i=1, \ldots, n ; n=20)$ set of variables, displayed in Table 1 , we eliminate the existing collinearities and we determined a set of new variables. These $m$ new components, $C_{j}(j=1, \ldots, m)$, replace the original variables associated to financial reporting and have the following form:

$$
C_{j}=\beta_{j 1} X_{1}+\beta_{j 2} X_{2}+\ldots+\beta_{j i} X_{i}+\ldots+\beta_{j n} X_{n}
$$

and $m \leq n$.

Based on the equation (1) it can be seen that the new components $\left(C_{j}\right)$ correspond to $m$ dimensions of financial reporting and are determined as a linear combination of initial variables $X_{i}$. The $C_{j}$ components comply with the assumption of independence that can be validated using statistical test $\chi^{2}$ or using KMO statistics (Kaiser-Meyer-Olkin) which determines the intensity of the relationship between $X_{i}$ variables (Jaba \& Robu, 2011). 
The KMO statistics has values in the $[0,1]$ interval, where 0 shows the absence of a correlation between the initial variables, and value 1 signals the existence of a significant correlation [49]. The PCA estimates the $\left(\beta_{j i}\right)$ parameters, which represent the contribution of each initial variable to the development of principal component (Jaba \& Robu, 2011).

Once there were identified the principal dimensions of the financial statements, in the second part of the study the influence of these dimensions on transparency in financial reporting will be analyzed using logistic regression analysis. This type of analysis uses regression models with alternative variables (Dodge, 2007), in this case the existence or absence of transparency in financial reporting.

The logistic regression model proposed in the analysis is defined by the relation (Bourbonnais, 2011):

$$
\ln \left[p_{i} /\left(1-p_{i}\right)\right]=\delta_{0}+\delta_{1} C_{1 i}+\ldots+\delta_{j} C_{j i}+\ldots+\delta_{m} C_{m i}+\varepsilon_{i}
$$

where $p_{i}$ shows the probability of transparency existence in financial reporting, defined based on an unqualified opinion or unqualified opinion but with insignificant observations. $C_{j}(j=1, \ldots, m)$ are the components identified through the PCA, $\delta_{j}(j=0, \ldots, m)$ represent the coefficients of the logistic regression model and $\varepsilon$ is the error component.

Logistic regression model parameters are estimated using maximum likelihood method (Dodge, 2007), and their testing was made using the likelihood ratio, a Pearson $\chi^{2}$ statistical test (Agresti, 2007).

To obtain research results, in this study the data analysis was performed using SPSS 20.0 statistical software.

\section{Results and discussion}

Starting from the research objectives proposed in the study, the main reached results consider the identification of the principal components of the Romanian BSE listed companies' financial statements, as well as the estimation of these components' influence on the transparency in financial reporting.

\subsection{Identification of the principal components of financial statements}

As a result of considering the 20 variables proposed in Table no. 1 in PCA, we identified the principal components of financial statements which explain $84.574 \%$ in the variation of the financial information reported by the Romanian BSE listed companies. A high value of the KMO test statistics (0.744) indicate the existence of a significant relation between the variables that remained in the analysis as a result of PCA use (Table no. 2).

\begin{tabular}{|c|c|c|c|}
\hline $\begin{array}{c}\mathrm{KMO}=0.744 \\
\mathrm{Sig}=0.000\end{array}$ & \multicolumn{3}{|c|}{ Total variance explained (rotated) } \\
\hline Component & Total & $\%$ of Variance & Cumulative \\
\hline $\mathrm{C}_{1}$ & 5.054 & 50.540 & 50.540 \\
\hline $\mathrm{C}_{2}$ & 1.901 & 19.013 & 69.553 \\
\hline $\mathrm{C}_{3}$ & 1.502 & 15.021 & 84.574 \\
\hline
\end{tabular}

Source: Own processing in SPSS 22.0

To determine the number of principal components corresponding to the financial statements, the study uses Bénzécri's criterion (Jaba \& Robu, 2011). Thus, we identified 3 principal components that have eigenvalues higher than one.

Using the above-mentioned criteria, in this study there were identified 3 principal components that are specific for the financial statements of the Romanian BSE listed companies (see Table no. 3 and Figure no. 1). The three $\left(C_{j}\right)$ identified components meet the independence hypothesis, fact that is emphasized as a result of removing 10 variables which displayed collinearity from the 20 initial variables $\left(X_{i}\right)$. 


\section{Figure no. 1. The number of principal components (Cj) identified through PCA}

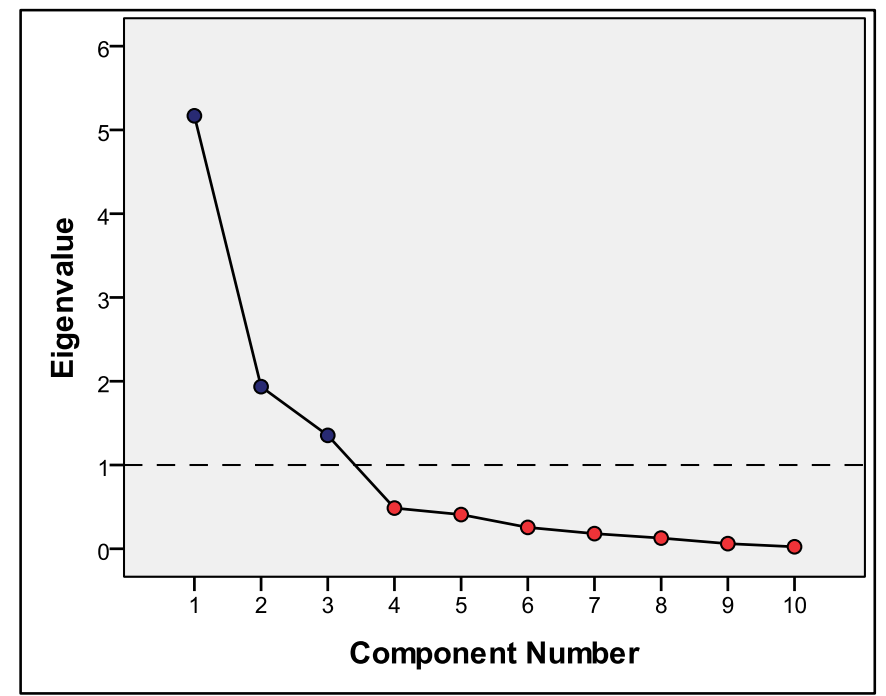

Source: Own processing in SPSS 22.0

Descriptive statistics corresponding to the variables considered in the PCA are displayed in Table no. 3.

Variables retained in the analysis are used to define the principal components of the Romanian BSE listed companies' financial statements.

\section{Table no. 3. Descriptive statistics for the variables considered in PCA}

\begin{tabular}{|c|c|c|c|c|c|}
\hline \multicolumn{2}{|c|}{ Variable } & Mean & Std. Deviation & Minimum & Maximum \\
\hline \multirow{10}{*}{$\begin{array}{l}\text { Retained } \\
\text { in the analysis }\end{array}$} & OI/TA & 0.0122 & 0.0762 & -0.1801 & 0.1359 \\
\hline & Ol/TO & 0.0122 & 0.1462 & -0.3513 & 0.2347 \\
\hline & OI/Pay & 0.1525 & 0.8250 & -1.8123 & 1.6214 \\
\hline & $\mathrm{NI} / \mathrm{Eq}$ & -0.0586 & 0.2513 & -0.8241 & 0.1650 \\
\hline & NI/TA & -0.0019 & 0.0774 & -0.1950 & 0.1217 \\
\hline & NI/TO & -0.0197 & 0.1705 & -0.4447 & 0.2187 \\
\hline & $\begin{array}{l}\text { CFT/TO } \\
\end{array}$ & 0.0132 & 0.0776 & -0.1337 & 0.2065 \\
\hline & CFT/TA & 0.0041 & 0.0365 & -0.0774 & 0.0936 \\
\hline & INV/CA & 0.2990 & 0.1955 & 0.0346 & 0.7187 \\
\hline & REC/CA & 0.4652 & 0.2201 & 0.1065 & 0.7987 \\
\hline \multirow{10}{*}{$\begin{array}{c}\text { Excluded from the } \\
\text { analysis }\end{array}$} & Eq/TA & 0.5622 & 0.2905 & -0.0288 & 0.9299 \\
\hline & TO/TA & 0.6434 & 0.4097 & 0.1112 & 1.6036 \\
\hline & CFO/OI & 1.0172 & 1.8956 & -2.2776 & 5.9730 \\
\hline & CFT/GP & 0.0540 & 1.2407 & -3.0527 & 2.7842 \\
\hline & FA/TA & 0.5801 & 0.2061 & 0.1932 & 0.9218 \\
\hline & CA/TA & 0.4197 & 0.2056 & 0.0782 & 0.8016 \\
\hline & Cash/TA & 0.0582 & 0.0737 & 0.0012 & 0.2606 \\
\hline & Cash/CA & 0.1430 & 0.1531 & 0.0035 & 0.5034 \\
\hline & LTD/TA & 0.1196 & 0.1231 & 0.0000 & 0.4097 \\
\hline & FL & -0.9121 & 6.5189 & -25.7687 & 3.8113 \\
\hline
\end{tabular}

Source: Own processing in SPSS 22.0 
Using the Correlation Matrix (Table no. 4) in which the correlations between the variables retained in the ACP are presented, the components resulting from the analysis can be identified. Each component is defined based on the links between the variables that display strong correlations between each other.

\section{Table no. 4. The correlation matrix between the variables retained in PCA}

\begin{tabular}{|c|c|c|c|c|c|c|c|c|c|c|}
\hline & OI/TA & OI/TO & OI/Pay & NI/Eq & NI/TA & NI/TO & CFT/TO & CFT/TA & INVICA & $\mathrm{REC} / \mathrm{CA}$ \\
\hline OI/TA & 1.000 & 0.878 & 0.843 & 0.734 & 0.944 & 0.821 & 0.075 & 0.156 & -0.204 & 0.051 \\
\hline Ol/TO & 0.878 & 1.000 & 0.844 & 0.677 & 0.844 & 0.920 & 0.072 & 0.143 & -0.232 & 0.065 \\
\hline OI/Pay & 0.843 & 0.844 & 1.000 & 0.641 & 0.791 & 0.755 & 0.064 & 0.123 & -0.275 & 0.106 \\
\hline NI/Eq & 0.734 & 0.677 & 0.641 & 1.000 & \begin{tabular}{|c|}
0.827 \\
\end{tabular} & 0.737 & 0.052 & 0.081 & -0.186 & 0.011 \\
\hline NI/TA & 0.944 & 0.844 & 0.791 & \begin{tabular}{|c|}
0.827 \\
\end{tabular} & 1.000 & 0.865 & 0.061 & 0.128 & -0.250 & 0.028 \\
\hline NI/TO & 0.821 & 0.920 & 0.755 & \begin{tabular}{|c|}
0.737 \\
\end{tabular} & 0.865 & 1.000 & 0.009 & 0.108 & -0.249 & 0.031 \\
\hline CFT/TO & 0.075 & 0.072 & 0.064 & 0.052 & 0.061 & 0.009 & 1.000 & 0.865 & -0.023 & -0.203 \\
\hline CFT/TA & 0.156 & 0.143 & 0.123 & 0.081 & 0.128 & 0.108 & 0.865 & 1.000 & -0.041 & -0.155 \\
\hline INV/CA & -0.204 & -0.232 & -0.275 & -0.186 & -0.250 & -0.249 & \begin{tabular}{|c|}
-0.023 \\
\end{tabular} & -0.041 & 1.000 & -0.480 \\
\hline $\mathrm{REC} / \mathrm{CA}$ & 0.051 & 0.065 & 0.106 & 0.011 & 0.028 & 0.031 & -0.203 & -0.155 & -0.480 & 1.000 \\
\hline
\end{tabular}

Source: Own processing in SPSS 22.0

Based on the correlations identified at the level of the variables proposed in the analysis and retained in PCA, in this study we identified the following the three principal components of the financial statements: the Return component (CR), the Cash flow component (CF) and the Current assets structure component (CS).

The Return component is defined based on the OI/TA, OI/TO, OI/Pay, NI/Eq, NI/TA, NI/TO variables, between which significant correlations exist. These financial ratios describe the profitableness of the operating activity depending on the existing assets, the registered turnover of the company, the workforce expenditures and the shareholders' equity.
The Cash flow component is defined by the CFT/TO, CFT/TA financial ratios and describes the value of the cash flows reported by the company, reported to the turnover or to the total assets.

The Current assets structure component is defined by the INV/CA, REC/CA financial ratios and includes the structure of the current assets, minus the cash and cash equivalents.

The influence of the $X_{i}$ variables, retained in the analysis on each of the 3 components of financial statements is emphasized through the results regarding the structure matrix in Table no. 5 .

\section{Table no. 5. The structure matrix of the identified components}

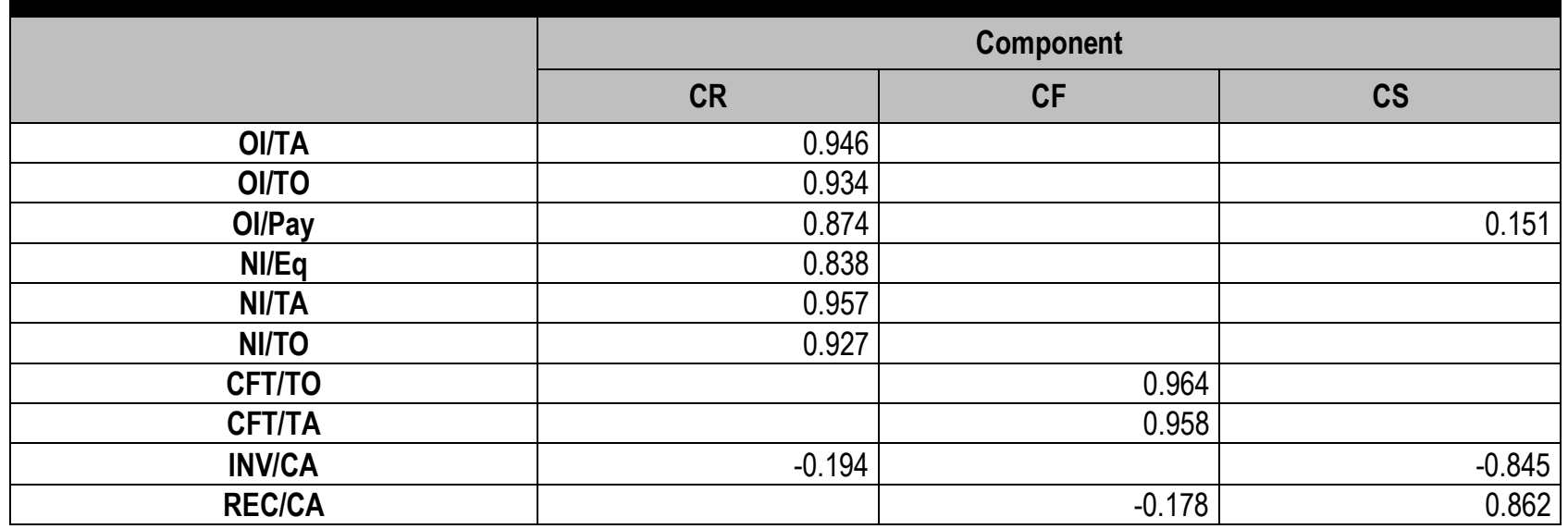

Source: Own processing in SPSS 22.0

No. 1(153)/2019 
Based on the data displayed in Table no. 5, we can notice that the variation of the Return component is significantly and positively influenced by $94.60 \%$ of the OI/TA variation, $93.40 \%$ of the OI/TO variation, $87.40 \%$ of the Ol/Pay variation, by $83.80 \%$ of the $\mathrm{NI} / \mathrm{Eq}$ variation, by $95.70 \%$ of the NI/TA variation and by $92.70 \%$ of the NI/TO variation. The Cash flow component is significantly and positively influenced by $96.40 \%$ of the CFI/TO variation and by $95.80 \%$ in the CFT/CA variation. The Current assets structure component is negatively influenced by $84.50 \%$ of the INV/CA variation and by $86.20 \%$ of the $R E C / C A$ variation. A decrease in the inventories (especially of goods sold) caused by their sale leads to an increase of the receivables value.

To estimate the scores of each company, corresponding to each dimension of financial reporting, Table no. 6 displays the estimations of the parameters of the functions associated to the three $C_{j}$ components.

\begin{tabular}{|c|c|c|c|}
\hline & \multicolumn{3}{|c|}{ Component } \\
\hline & $C R$ & $C F$ & $C S$ \\
\hline Ol/TA & 0.191 & -0.003 & -0.032 \\
\hline OI/TO & 0.186 & -0.004 & -0.010 \\
\hline Ol/Pay & 0.169 & 0.001 & 0.040 \\
\hline NI/Eq & 0.174 & -0.029 & -0.059 \\
\hline NI/TA & 0.194 & -0.015 & -0.032 \\
\hline NI/TO & 0.189 & -0.033 & -0.027 \\
\hline CFT/TO & -0.036 & 0.515 & 0.020 \\
\hline CFT/TA & -0.023 & 0.511 & 0.037 \\
\hline INV/CA & 0.030 & -0.096 & -0.582 \\
\hline REC/CA & -0.063 & -0.039 & 0.592 \\
\hline
\end{tabular}

Source: Own processing in SPSS 22.0

From the data presented in Table no. 6, the score functions of each of the three components are calculated with the following formulas:

$$
\begin{gathered}
C R=0.1910 \mathrm{I} / \mathrm{TA}+0.186 \mathrm{OI} / \mathrm{TO}+0.169 \mathrm{OI} / \mathrm{Pay} \\
+0.174 \mathrm{NI} / \mathrm{Eq}+0.194 \mathrm{NI} / \mathrm{TA}+0.189 \mathrm{NI} / \mathrm{TO}- \\
0.036 \mathrm{CFT} / \mathrm{TO}-0.023 \mathrm{CFT} / \mathrm{TA}+0.030 \mathrm{INV} / \mathrm{CA}- \\
0.063 R E C / \mathrm{CA}
\end{gathered}
$$

$$
\begin{gathered}
C F=-0.0030 \mathrm{I} / \mathrm{TA}-0.0040 \mathrm{I} / \mathrm{TO}+0.0010 \mathrm{I} / \mathrm{Pay}- \\
0.029 \mathrm{NI} / \mathrm{Eq}-0.015 \mathrm{NI} / \mathrm{TA}-0.033 \mathrm{NI} / \mathrm{TO} \\
+0.515 \mathrm{CFT} / \mathrm{TO}+0.511 \mathrm{CFT} / \mathrm{TA}-0.096 \mathrm{NV} / \mathrm{CA}- \\
0.039 \mathrm{REC} / \mathrm{CA}
\end{gathered}
$$

$$
\begin{gathered}
\text { CS }=-0.0320 \mathrm{I} / \mathrm{TA}-0.0100 \mathrm{I} / \mathrm{TO}+0.0400 \mathrm{I} / \mathrm{Pay}- \\
0.059 \mathrm{NI} / \mathrm{Eq}-0.032 \mathrm{NI} / \mathrm{TA}-0.027 \mathrm{NI} / \mathrm{TO} \\
+0.020 \mathrm{CFT} / \mathrm{TO}+0.037 \mathrm{CFT} / \mathrm{TA}-0.582 \mathrm{INV} / \mathrm{CA} \\
+0.592 \mathrm{REC} / \mathrm{CA}
\end{gathered}
$$

Using equations (3), (4) and (5) associated to the score functions corresponding to each component of financial statements, we determine the reporting scores for each company in the sample. Descriptive statistics regarding the calculated scores for each dimension are displayed in Table no. 7.

\section{Table no. 7. Descriptive statistics for the estimated scores corresponding to the components identified in the PCA}

\begin{tabular}{|c|c|c|c|c|}
\hline Component & Mean & Std. Deviation & Minimum & Maximum \\
\hline CR & 0.000 & 1.000 & -2.939 & 1.644 \\
\hline CF & 0.000 & 1.000 & -2.184 & 2.671 \\
\hline CS & 0.000 & 1.000 & -2.328 & 1.875 \\
\hline
\end{tabular}

Source: Own processing in SPSS 22.0 
For the Return component, a positive score value shows the existence of profitability within a company, while negative values indicate loses. For the Cash flow component, a positive score value indicates the fact that the used assets generate future economic benefits, while negative values indicate decreases in the benefits or debt payments that lead to cash outflows. For the Current assets structure component, a positive score value indicate the fact that inventories are predominant in the structure of the current assets, while negative values indicate the fact that in the structure of the assets, receivables are predominant, with direct influence on the company's liquidity and solvency.

Once the scores were estimated for each company, in each of the 2011-2016 financial years, we test the influence of the financial statements' component on the financial reporting transparency.

\subsection{The influence of the financial statements' components on the financial reporting transparency}

Using the logistic regression analysis, we estimated and tested the influence of the previously identified components of the financial statements, on the financial reporting transparency. The transparency existence was determined based on the unqualified opinions or unqualified opinions with insignificant observations that were expressed by the financial auditor. If other types of audit opinions were expressed in the audit reports, than we consider there is no (or not enough) transparency in financial reporting.

The parameters estimates of the regression models proposed in the analysis, equation (2), in which the estimated scores of the three previously identified components are included are displayed in Table no. 8.

Table no. 8. Parameters estimates for the proposed logistic regression model

\begin{tabular}{|c|c|c|c|c|c|}
\hline Variables & B & S.E. & Wald & Sig. & $\operatorname{Exp}(B)$ \\
\hline CR & 0.575 & 0.145 & 15.760 & 0.000 & 1.777 \\
\hline CF & -0.016 & 0.154 & 0.011 & 0.916 & 0.984 \\
\hline CS & -0.147 & 0.153 & 0.917 & 0.338 & 0.864 \\
\hline Constant & 1.150 & 0.155 & 55.128 & 0.000 & 3.159 \\
\hline \multicolumn{3}{|c|}{$\chi^{2}-$ Omnibus test of model coefficient: } & 17.318 & 0.001 & \\
\hline \multicolumn{3}{|c|}{-2 Log likelihood: } & 263.776 & & \\
\hline \multicolumn{3}{|r|}{ Cox \& Shell R Square: } & 0.067 & & \\
\hline \multicolumn{3}{|r|}{ Nagelkerke R Square: } & 0.099 & & \\
\hline \multicolumn{3}{|c|}{ Observations: } & 372 & & \\
\hline
\end{tabular}

Source: Own processing in SPSS 22.0

From the data in Table no. 8, we can notice that within the analyzed sample, the Return component has the most significant influence on the financial reporting transparency. An increase in the companies' profitability (with a unit at the level of the estimated score of the PCA-identified component) leads to a $77 \%$ increase of the probability that the company reports this information in a transparent manner. In this case, the auditor's opinion will be an unqualified one or unqualified but with insignificant observations. The influence of profitability on transparency can be explained by the fact that, alongside with the improvement of financial performances, the company becomes more and more attractive to investors, which, in turn, are willing to receive more information regarding the reported results of the company.

We can see that the other components of financial statements, identified by the PCA, do not have a significant influence on transparency in financial reporting. This can be explained by the fact that the information regarding the cash flows (collected and paid), as well as the ones regarding the structure of the assets are not that important to investors, as they do not describe the future generated benefits. 


\section{Conclusions}

The results obtained in the study have led to the achievement of the research objectives and the validation of the research hypothesis proposed for testing and validation.

Thus, in this study there were estimated three principal components of the financial statements that synthesize the informational content useful to investors. The Return component is defined by the financial ratios describing the profitability of the operating activity taking into consideration the total assets, the reported turnover of the company, the workforce expenditures and the shareholders' equity. The Cash flow component is defined by the variables describing the value of the cash flows of the company (as effective economic benefits), reported to the turnover or to the total assets. The Current assets structure component is defined by the indicators displaying the structure of current assets, without the cash and cash equivalents assets.

As the principal components were identified, we tested their influence on the transparency in financial reporting, assessed based on the audit opinion. The research results show that, of the three identified components, only the Return component has a significant influence on financial reporting transparency. The other two components have insignificant influence. The significant influence of the Return component on the transparency can be explained by the fact that investors are mainly interested in decision making by the information regarding the future profits/benefits to be gained as a result of placing invested capitals in the company. Such a situation can though lead to accounting manipulation or earnings management, within the company, of the information regarding the profitability (performance), just to influence the investors' decisions. To this regard, an increase in the financial performance, given the conditions of the eventual investors' reward, also mandates an increase of the financial reporting transparency just to display such information as transparent as possible.

Ensuring the financial reporting transparency supports the faithful representation of the financial position and performance of the company, allowing it to allocate resources better and a better, and also an improvement in management of the registered benefits. These benefits could be used to start social projects or which are to lead to environmental protection, thus ensuring a sustainable development of the company.

The main limits of this research are represented by the low size of the analyzed sample, just 62 companies. This is due to the low number of BSE listed companies, but in the future research we are to enlarge the size of the sample by including other capital markets too, at least in Eastern Europe.

As for the sustainable development, another research limit consists of the inclusion in the analysis of the financial dimension only, but future directions also consider the evaluation of the social and environmental dimensions influence on the sustainable development.

\section{REFERENCES}

1. Abeysekera, I., A template for integrated reporting. Journal of Intellectual Capital 2013, 14(2), 227-245.

2. Adiloglu, B., Vuran, B., The relationship between financial ratio and transparency levels of financial information disclosures within the scope of corporate governance: evidence from Turkey. The Journal of Applied Business Research 2012, 28(4), 543-554.

3. Agresti, A., An introduction to categorical data analysis, John Willey \& Sons: New Jersey, USA, 2007, p. 36.

4. Arrow, K. J., The economics of information 1984, Vol. 4, Belknap Press of Harvard University Press: Cambridge, United Kingdom, 1984: p. 138.
5. Azapagic, A., Developing a framework for sustainable development indicators for the mining and minerals industry. Journal of Cleaner Production 2004, 12, 639-662.

6. Azapagic, A., Perdan, S., Indicators of sustainable development for industry: A general framework. Process Safety and Environmental Protection 2000, 78(B4), 243-261.

7. Bansal, P., Evolving sustainably: a longitudinal study of corporate sustainable development. Strategic Management Journal 2005, 26, 197-218.

8. Barth, M., Landsman, W., Lang, M., International Accounting Standards and Accounting Quality. Journal of Accounting Research 2008, 46(3), 467498. 
9. Boerner, H., Sustainability and ESG reporting frameworks: issuers have GAAP and IFRS for reporting financial - what about reporting for intangibles and non-financial? Corporate Finance Review 2011, 15(5), 34-37.

10. Bourbonnais, R. Économetrie. Manuel et exercices corrigés, $8^{e}$ édition, Dunod: Paris, France, 2011, p. 322.

11. Brown, S., Lo, K., Lys, T, Use of $R^{2}$ in accounting research: measuring changes in value relevance over the last four decades. Journal of Accounting and Economics 1999, 28, 83-115.

12. Bunget, O., Caciuc, L., Dumitrescu, A., Farcane, N., Popa, A., The impact of IAS/IFRS on Romanian accounting rules, 2009: http://mpra.ub.unimuenchen.de/id/eprint/18279 (accessed on 22 September 2013).

13. Dobre, E., Stanila, G.O., Brad, L., The Influence of Environmental and Social Performance on Financial Performance: Evidence from Romania's Listed Entities Sustainability 2015, 7(3), 25132553.

14. Dodge, Y. Statistique. Dictionnaire encyclopédique, Springer: Paris, France, 2007, p. 451.

15. Farcaş, T. V., The Development of Corporate Reporting over Time: From a Traditional System to an Integrated System. Audit Financiar 2015, 13(4), 16-113.

16. Fauzi, H., Svensson, G., Rahman, A.A., „Triple Bottom Line" as "Sustainable Corporate Performance": A Proposition for the Future. Sustainability 2010, 2(5), 1345-1360.

17. Filip, A., Raffournier, B., The value relevance of earnings in a transition economy: The case of Romania. The International Journal of Accounting 2010, 45, 77-103.

18. Hayes, R., Dassen, R., Schilder, A., Wallage, P., Principles of Auditing. An Introduction to International Standards of Auditing, $2^{\text {nd }} \mathrm{ed}$., Pearson Education, 2005, pp. 10-11.

19. Heemskerk, B., Pistorio, P., Scicluna, M., Sustainable development reporting. Striking the balance, World Business Council for Sustainable Development, 2002.

20. Hockerts, K., The Sustainability Radar: A Tool for the Innovation of Sustainable Products and Services. Greener Management International 1999, 25, 29-49.
21. IAS 1 (International Accounting Standard 1), "Presentation of Financial Statements": http://eifrs.ifrs.org/eifrs/bnstandards/en/2015/ias01. pdf (accessed on 15 May 2015).

22. International Auditing and Assurance Standards Board - IAASB 2016-2017 Handbook of International Quality Control, Auditing, Review, Other Assurance, and Related Services Pronouncements, International Federation of Accountants, New York, 2016.

23. Ionaşcu, M., Ionaşcu, I., Săcărin, M., Minu, M., IFRS adoption in developing countries: the case of Romania. Journal of Accounting and Management Information Systems 2014, 13(2), 311-350.

24. Istrate, C., Impact of IFRS on the accounting numbers of Romanian listed companies. Journal of Accounting and Management Information Systems 2014, 13(3), 446-491.

25. Jaba, E., Robu, I.-B., Obtaining Audit Evidence for Testing the "Going Concern" Assumption Using Advanced Statistical Methods to Analyze the Influence on Overall Borrowing Rate. Audit Financiar 2011, 9(2), 37-46.

26. James, M. L. The benefits of sustainability and integrated reporting: an investigation of accounting majors' perceptions. Journal of Legal, Ethical and Regulatory Issues 2014, 17(2), 93-113.

27. Krajnc, D., Glavic, P., A model for integrated assessment of sustainable development. Resources, Conservation and Recycling 2005, 43, 189-208.

28. Krajnc, D., Glavic, P., How to compare companies on relevant dimensions of sustainability. Ecological Economics 2005, 55, 551- 563.

29. Labuschagne, C., Brent, A.C., van Erck, R.P.G. Assessing the sustainability performances of industries. Journal of Cleaner Production 2005, 13, 373-385.

30. Lackmann, J., Ernstberger, J., Stich, M., Market reactions to increased reliability of sustainability information. Journal of Business Ethics 2012, 107(2), 111-128.

31. Lebart, L., Piron, M., Morineau, A., Statistique exploratoire multidimensionnelle. Visualisation et inférences en fouille de données, $4^{\mathrm{e}}$ édition, Dunod: Paris, France, 2006: pp. 186-190.

32. Lopez, M.V., Garcia, A., Rodriguez, L., Sustainable Development and Corporate Performance: A Study 
Based on the Dow Jones Sustainability Index. Journal of Business Ethics 2007, 75, 285-300.

33. Lungu, C. I., Caraiani, C., Dascălu, C., Guşe, R. G., Exploratory study on social and environmental reporting of European companies in crises period. Accounting and Management Information Systems 2011, 10(4), 459-478.

34. McGuire J.B., Sundgren A., Scheneeweis T., Corporate social responsibility and firm financial performance. Academy of Management Journal 1988, 31(4), 854-872.

35. McWilliams, A., Siegel, D., Corporate Social Responsibility and Financial Performance: Correlation or Misspecification? Strategic Management Journal 2000, 21(5), 603-609.

36. Modigliani, F., Miller, M.H., The Cost of Capital, Corporation Finance and the Theory of Investment. The American Economic Review 1958, 44(3), 261297.

37. Morris, R.D., Pham, T., Gray, S.J., The Value Relevance of Transparency and Corporate Governance in Malaysia Before and After Asian Financial Crisis. ABACUS 2011, 47(2), 205-233.

38. Ohlson, J.A., Earnings, Book Values, and Dividends in Equity Valuation. Contemporary Accounting Research 1995, 11, 661-687.

39. Orlitzky, M., Schmidt, F.L, Rynes, S.L., Corporate Social and Financial Performance: A Metaanalysis. Organizational Studies 2003, 24(3), 403-441.

40. Ortas, E., Álvarez, I., Garayar, A., The Environmental, Social, Governance, and Financial Performance Effects on Companies that Adopt the United Nations Global Compact. Sustainability 2015, 7(2), 1932-1956.

41. Palttala, P., Vos, M., Quality Indicators for Crisis Communication to Support Emergency Management by Public Authorities. Journal of Contingencies and Crisis Management 2012, 20(1), 39-51.

42. Patel, A. S., Balic, A., Bwakira, L., Measuring transparency and disclosure at firm-level in emerging markets. Emerging Markets Review 2002, 3(4), 325-337.

43. Pinnuck, M., A Review of the Role of Financial Reporting in the Global Financial Crisis Australian Accounting Review 2012, 22(6), 1-14.
44. Preston, L.E, O'Bannon, D.P., The Corporate Social-Financial Performance Relationship: A Typology and Analysis. Business and Society 1997, 36(4), 419-429.

45. Rio Declaration on Environment and Development, The United Nations Conference on Environment and Development, Having met at Rio de Janeiro from 3 to 14 June 1992, United Nations publication, Sales No. E.73.II.A.14 and corrigendum), chap. I.

46. Săcărin, M., Impactul adoptării pentru prima dată a IFRS de către societățile nefinanciare cotate la Bursa deValori Bucureşti. Audit Financiar 2014, 12(1), 46-54.

47. Singh, R.K., Murty, H.R., Gupta, S.K., Dikshit, A.K., An overview of sustainability assessment methodologies. Ecological Indicators 2009, 9, 189212.

48. Sloan, R., Do Stock Prices Fully Reflect Information in Accruals and Cash Flows about Future Earnings? The Accounting Review 1996, 71(3), 289-315.

49. Stanwick, P.A., Stanwick, S.D., The Relationship Between Corporate Social Performance and Organizational Size, Financial Performance, and Environmental Performance: An Empirical Examination. Journal of Business Ethics 1998, 17(2), 195-204.

50. Stiglbauer, M., Transparency \& disclosure on corporate governance as a key factor of companies success: a simultaneous equations analysis for Germany. Problems and Perspectives in Management 2010, 8(1), 161-173.

51. Tschopp, D., Nastanski, M., The Harmonization and Convergence of Corporate Social Responsibility Reporting Standards. Journal of Business Ethics 2014, 125(1), 147-162.

52. Turner, J.L., Mock, T.J., Coram, P.J., Gray, G.L., Improving Transparency and Relevance of Auditor Communications with Financial Statement Users. Current Issues in Auditing 2010, 4(1), 1-8.

53. Visser, W.T., Sustainability reporting in South Africa. Corporate Environmental Strategy 2002, 9(1), 79-85. 